\title{
Kikuchi-Fujimoto disease
}

\author{
Aneta Kołodziej-Kłęk', Renata Orłowska-Florek', Krystyna Gałązka², Marek Grzywa1 \\ 1 Department of Internal Diseases, Nephrology and Endocrinology, Regional Hospital No. 2, Rzeszów, Poland \\ 2 Department of Clinical and Experimental Pathomorphology, Jagiellonian University School of Medicine, Kraków, Poland
}

\section{KEY WORDS}

cervical

lymphadenopathy,

histiocytic

necrotizing

lymphadenitis,

Kikuchi-Fujimoto

disease
Correspondence to: Renata Orłowska-Florek, MD, PhD, Oddziat Chorób Wewnętrznych, Nefrologii i Endokrynologii z Pracownią Medycyny Nuklearnej Szpital Wojewódzki nr 2 , ul. Lwowska 60,

35-301 Rzeszów, Poland, phone/fax: +48-17-857-87-34 e-mail: florek9@op.pl Received: September 24, 2009. Revision accepted: November 9, 2009. Conflict of interest: none declared. Pol Arch Med Wewn. 2009; 119 (12): 826-829

Copyright by Medycyna Praktyczna, Kraków 2009

\section{ABSTRACT}

We present the case of a 27-year-old woman with local cervical lymphadenopathy without other symptoms. Due to a gradual progression of lesions, a biopsy was performed, and a specimen excised from an enlarged lymph node was subjected to histological examination. Kikuchi-Fujimoto disease (KFD), that is histiocytic necrotizing lymhadenitis, was diagnosed. Lymphadenopathy resolved without medical treatment over 6 months. KFD should be considered in the differential diagnosis of lymphadenopathy, even though this disease rarely occurs in Poland.

INTRODUCTION Kikuchi-Fujimoto disease (KFD), or histiocytic necrotizing lymphadenitis, is a rare, usually benign, self-limited disease. It occurs almost exclusively among Asians. ${ }^{1}$ KFD was first described in Japan in 1972 by 2 independent authors, Kikuchi and Fujimoto. Since then, it has been reported worldwide. ${ }^{2,3}$ We present the case of KFD detected in a 27-year-old white Polish woman.

CASE REPORT A 27-year-old white woman was referred to the Endocrinology Clinic at Regional Hospital No. 2 in Rzeszów with unilateral cervical lymphadenopathy that persisted for 1 month. She had no other complaints. She had a history of recurrent upper respiratory tract infections, including pharyngitis about 1 month before the cervical nodes became enlarged.

On admission, the patient was in a good general condition. The physical examination revealed 2 enlarged nodes, approximately 2.0 to $2.5 \mathrm{~cm}$ in diameter, located in the right upper part of the neck behind the sternocleidomastoid muscle. The lymph nodes were tenderless, moveable, had slightly increased consistency and a smooth surface. No other lymph nodes were palpable.

A chest X-ray and abdominal ultrasonography did not show any abnormalities. Ultrasonography of the neck confirmed the presence of 2 enlarged oval lymph nodes (the dominant one of $2.0 \times 2.5 \mathrm{~cm}$ ) with normal hili.

The following laboratory test results were normal: cell blood counts, leukocyte differential count, blood smear, erythrocyte sedimentation rate (ESR), C-reactive protein (CRP), urinalysis, serum sodium, potassium, chloride, calcium, phosphorus, iron, glucose, urea, creatinine, uric acid, protein, transaminases, bilirubin, alkaline phosphatase, amylase, $\gamma$ glutamyltranspeptidase, lipid profile, immunoglobulins, and thyroid hormones. The serum complement component $3 \mathrm{lev}$ el was within normal range (1.23 g/l; 0.9-1.8 g/l), while the complement component 4 level was slightly elevated (0.48 g/l; 0.1-0.4 g/l). Mononucleosis, cytomegaly, and toxoplasmosis serology tests were negative. Neoplastic markers (carcinoembryonic antigen, $\alpha$-fetoprotein, cancer antigens: CA 125, CA 19-9, 15.3) were normal.

A fine needle aspiration biopsy of the cervical nodes revealed a mixed population of lymphocytes with no atypical cells and a number of histiocytes, which suggested reactive lymphadenopathy.

A 2-month ultrasound follow-up showed a gradual enlargement of the cervical nodes to the size of $2 \times 3 \mathrm{~cm}$. We did not observe any new signs or symptoms. The results of control laboratory tests were normal. The patient was not treated.

An excision biopsy of one of the enlarged lymph nodes was performed in August 2008. Histological examination, performed in the Department of Pathomorphology at the Jagiellonian University School of Medicine in Kraków, Poland, revealed partial effacement of the normal nodal architecture, with reduced follicular zone and T-zone expansion, with altered structure. Focal coagulative necrosis with cellular debris without neutrophil infiltrates was present mainly at the periphery of the lymph node. The necrotic 
FIGURE 1 Peripheral part of the lymph node with partial effacement of normal nodal architecture; hematoxylin and eosin staining; magnification $\times 10$

FIGURE 2 The area of effacement of the normal nodal architecture with histiocytes and plasmacytoid monocytes infiltration, focal coagulative necrosis with cellular debris without infiltrates containing neutrophils; hematoxylin and eosin staining; magnification $\times 40$

FIGURE 3 Histiocytes with "crescentic" morphology in cellular infiltration; hematoxylin and eosin staining; magnification $\times 60$

FIGURE 4 Normal nodal architecture with germinal center in the other part of lymph node; hematoxylin and eosin staining; magnification $\times 40$
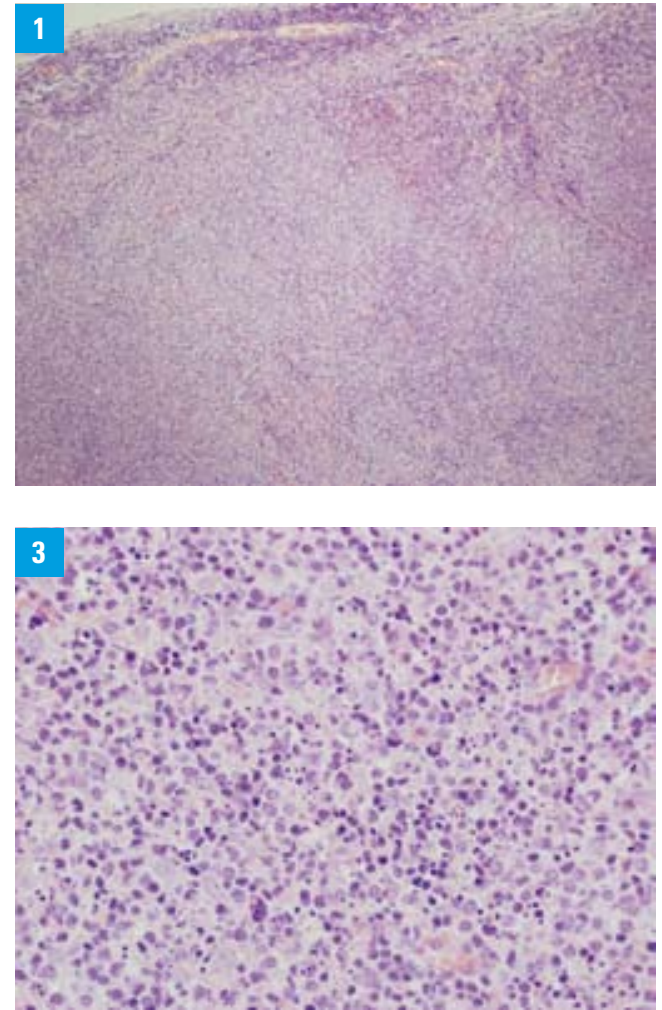

areas were surrounded by zone infiltrates composed of histiocytes, plasmacytoid monocytes CD68+/MPO+/-, the small CD3+ T cells with $\mathrm{CD} 8$ + to $\mathrm{CD} 4$ + ratio markedly higher than normal, few CD20+ B cells of varying size, with the presence of large immunoblast-like cells, some CD30 positive (activated lymphocytes without coexpression of epithelial membrane antigen and/ or anaplastic lymphoma kinase 1). A few plasma cells, located at the periphery of the lymph node, were visible (FIGURES 1, 2, 3, 4).

The diagnosis of histiocytic necrotizing lymphadenitis (KFD) was established on the basis of histological features.

The patient has been followed since the diagnosis. Lymphadenopathy resolved spontaneously after 6 months and no other symptoms developed.

DISCUSSION KFD is a rare, self-limited, and usually benign condition. The association between KFD and systemic lupus erythematosus (SLE) is well documented. It can precede or coincide with SLE. ${ }^{4}$ Associations with Still's disease, Sweet's syndrome, ${ }^{1}$ Hashimoto disease, ${ }^{2}$ antiphospholipid syndrome, or neoplastic disease ${ }^{5,6}$ have also been reported.

KFD affects mainly Asians. Over half of cases were found in the Japanese population, although the disease can sporadically occur worldwide, ${ }^{2,4,7}$ including Poland. ${ }^{3,8}$ It usually affects women, and the male to female ratio is $4: 1^{4}$ or $5: 1{ }^{1}$

The patient age ranges from 1 month to 80 years, ${ }^{1,2}$ but most cases of the disease are detected in the third decade. ${ }^{1,4}$

Some authors reported seasonal distribution with the highest incidence in spring and summer. Koh et al. ${ }^{1}$ and Hsin-Liang et al. ${ }^{6}$ observed that it
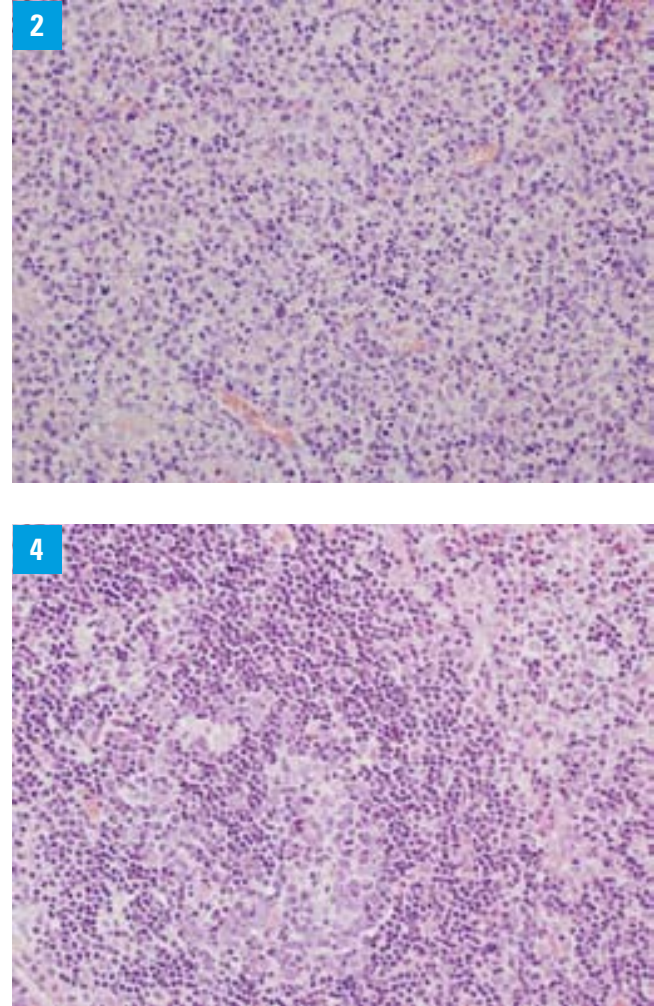

developed more often in March and July, respectively, as compared with other months.

The cause of the disease remains unknown. It has been suggested that KFD may result from ex cessive immune response to an infectious agent including Epstein-Barr virus, rubella virus, human herpesvirus 6, human immunodeficiency virus, parvovirus B19, Yersinia enterocolica, Toxoplas ma gondii, ${ }^{1,4,6,7}$ or any physical or chemical agent. ${ }^{6}$ A role of autoimmunity and genetic susceptibility in abnormal and hyperimmune response has been postulated in the pathogenesis of KFD. ${ }^{5}$

In the view of a histological and clinical similarity and the well-documented association with SLE, ${ }^{4}$ some authors hypothesized that KFD is a self-limited SLE-like autoimmune condition. ${ }^{3,6}$ A programmed cell death is a fundamental biological process in the pathogenesis of KFD. CD8+ $\mathrm{T}$ cells activated by foreign agents induce excessive and defective apoptosis of CD4+ cells. Apoptotic cells are engulfed by macrophages leading to necrotizing lymphadenitis, ${ }^{5,6}$ but without neutrophilic infiltrate (without suppuration).

KFD is characterized by lymph node enlargement, most commonly in the neck. ${ }^{6}$

Lymphadenopathy is usually unilateral, affecting the posterior triangle of the neck. ${ }^{5,6}$ In $20 \%$ of cases it is accompanied by pain, ${ }^{1}$ and in $25 \%$ by fever. ${ }^{1,6}$ Less frequent signs and symptoms include night sweats, nausea, vomiting, weight loss, myalgia, and rash. ${ }^{5,6}$

Lymphadenopathy rarely affects axillary (14\%), supraclavicular (12\%), inguinal, or mesenteric lymph nodes. ${ }^{1,6}$ The diameter of affected lymph nodes ranges from 1 to $9 \mathrm{~cm} .^{6}$ The involvement of extranodal sites such as the liver, spleen, and skin is rare. ${ }^{6}$ 
No specific laboratory tests are available to diagnose KFD. ${ }^{6}$ The results of laboratory tests are usually normal. Abnormal findings typically include leucopenia $\left(<4000 \mathrm{~mm}^{3}\right),{ }^{1,5}$ rarely leucocytosis, an elevated ESR, anemia, increased CRP levels, and hepatic dysfunction..$^{5,6}$

The diagnosis of KFD can only be established using an excisional lymph node biopsy. Typical histological findings include focal areas of coagulative necrosis with karyorrhectic debris surrounded by histiocytes, plasmocytoid monocytes, and lymphocytes. Different monocyte-lineage cells, some of which may demonstrate phagocytic properties, are also present. Neutrophils are typically absent, which allows to differentiate KFD from bacterial lymphadenitis. ${ }^{2}$

The absence of hematoxylin bodies and the presence of only a few plasma cells help to distinguish KFD from SLE-related lymphadenopathy. The polymorphic components of a lymph node affected by KFD, with a high occurrence of large lymphocytes and CD8+ T lymphocytes can falsely suggest lymphoma. ${ }^{1,3} \mathrm{KFD}$ is most commonly misdiagnosed as malignant lymphoma ${ }^{2}$ and occasionally as tuberculosis. ${ }^{2,6}$

Spontaneous, complete resolution of symptoms usually occurs within the period of 1 to 4 months. Only severe cases require treatment with anti-inflammatory drugs. Fever and tender lymph nodes are the most frequent reasons why treatment is started. Pharmacological treatment includes nonsteroidal anti-inflammatory drugs, minocycline, ciprofloxacin, hydrochloroquine, and corticosteroids. Successful combined treatment of KFD with maximum doses of steroids and intravenous immunoglobulin has been reported. . $^{4-6}$

The recurrence rate of KFD is estimated at $3 \%$ to $4 \% .^{5}$

Patients with KFD require a follow-up for several years to rule out the development of autoimmune disease, particularly SLE and lymphoma. ${ }^{7}$

In the present case, the course of the disease was benign and the symptoms resolved spontaneously.

Summary KFD is a rare cause of enlarged lymph nodes in white population - it is more prevalent among Asians. KFD should be considered in the differential diagnosis of lymphadenopathy, particularly in young women with cervical lymphadenopathy. An accurate diagnosis requires a close collaboration between clinicians and pathologists. Early diagnosis of KFD allows to reduce stress caused by alarming symptoms and to avoid unnecessary treatment. KFD is a self-limited condition that usually resolves spontaneously. $\mathrm{Pa}$ tients with KFD require a long-term follow-up to exclude the development of autoimmune diseases, particularly SLE and lymphoma.

\section{REFERENCES}

1 Koh YH, Choi IJ, Lee YB. Subacute necrotizing lymphadenitis: I. Histopathologic study. Yonsei Med J. 1985; 26: 44-47.

2 Bennie MJ, Bowles KM, Rankin SC. Necrotizing cervical lymphadenopathy caused by Kikuchi-Fujimoto disease. Br J Radiol. 2003; 76: 656-658.

3 Kowal M, Skóra D, Dmoszyńska A, Koktysz M. [Kikuchi Disease - case report]. Acta Haematol Pol. 1998, 29: 141-143. Polish.

4 Murthy SC, Dandin SM, Dandin AS, Patwardan MY. Kikuchi's disease associated with systemic lupus erythematosus. Indian J Dermatol Venereol Leprol. 2005; 71: 338-341.

5 Bosch X, Guilabert A. Kikuchi-Fujimoto disease. Orphanet J Rare Dis 2006; 1 : 18.

6 Yu HL, Lee SS, Tsai HC, et al. Clinical manifestation of Kikuchi's disease in southern Taiwan. J Microbiol Immunol Infect. 2005; 38: 35-40.

7 Küçükardali Y, Cankir Z, Top C, et al. Kikuchi's disease: report of one case and an overview. The Internet Journal of Emergency and Intensive Care Medicine. 2003; 6. http://www.ispub.com/journal/the internet journal_of_emergency_and_intensive_care_medicine/volume_6_number_2_3/ article/kikuchi_s_disease_report_of_one_case_and_an_overview. html. Accessed April, 2009.

8 Papla B, Urbańczyk K, Gałązka K. Histiocytic necrotizing lymphadenitis without granulocytic infiltration (the so called Kikuchi-Fujimoto disease). Polish J Pathol. 2008; 59: 55-61. 


\section{Choroba Kikuchi i Fujimoto}

Aneta Kołodziej-Kłęk', Renata Orłowska-Florek', Krystyna Gałązka², Marek Grzywa'1

1 Oddział Chorób Wewnętrznych, Nefrologii i Endokrynologii z Pracownią Medycyny Nuklearnej, Szpital Wojewódzki nr 2, Rzeszów

2 Katedra i Zakład Patomorfologii Klinicznej i Doświadczalnej, Uniwersytet Jagielloński, Collegium Medicum, Kraków

\section{SŁOWA KLUCZOWE}

choroba Kikuchi

i Fujimoto,

limfadenopatia

szyjna, martwicze

histiocytarne

zapalenie węzłów

chłonnych

\section{STRESZCZENIE}

Przedstawiamy przypadek 27-letniej kobiety, u której wystąpiło lokalne powiększenie węztów chłonnych szyi bez innych objawów chorobowych. Wobec stopniowej progresji zmian przeprowadzono ocenę histopatologiczną pobranego chirurgicznie węzła. Ustalono rozpoznanie choroby Kikuchi i Fujimoto, czyli martwiczego, histiocytarnego zapalenia węzłów chłonnych. Powiększenie węzłów chłonnych ustąpiło samoistnie w ciągu 6 miesięcy. Chorobę Kikuchi i Fujimoto, mimo że jest to jednostka rzadko występująca w Polsce, należy uwzględniać w diagnostyce różnicowej limfadenopatii. 